\title{
Lynn Hershman and the Creation of Multiple Robertas
}

\section{Roberta Mock}

What is authentic, unique and original in our particular point in time has changed enormously! I think the gesture of sharing is important enough to give up some of the other terms, and the historically embedded values of "uniqueness," "originality," and "authenticity" in art are conceptual architectures aimed towards scalable release. (Lynn Hershman Leeson qtd. in claire_w, 2009) ${ }^{1}$

According to Meredith Tromble, Lynn Hershman's is 'a story of a body with more minds than it knows what to do with or of a mind manifesting through several bodies... The tributary themes of her work - memory, voyeurism, surveillance, seduction, and authenticity - flow from the condition of multiplicity' (Tromble, 2005a: 201). In this chapter, I will explore the manifestations and effects of this multiplicity in an artwork that has been regenerating across forms, genres and disciplinary boundaries for nearly forty years. I do so primarily by positioning myself auto/biographically in its narrative construction and by augmenting my voice with that of Jacques Derrida. According to Derrida, 'I' not only 'mark(s) first of all a division in what will have been able to appear in the beginning' but also 'I mark(s) and multiply (multiplies) the division' (Derrida, 1998: 196-197). This is as applicable to Hershman, the 'originating' artist, as it is to me, a 'percipient' who has been affected by the traces of, and thereafter absorbed into, Hershman's work. ${ }^{2}$ I am interested in particular, and almost certainly narcissistically, in the performance of naming and the role it plays in an aesthetic agency that revolves paradoxically around singularity and iterability.

\section{Lynn-Roberta}

From 1974 to 1978 (probably), Hershman created a 'private performance' in which she lived the experiences of a fictitious character named Roberta Breitmore. By the end of this period, three 
other women known as 'Roberta Multiples' were performing (as) Roberta and she was eventually ritually killed by Hershman in order to close and transform a manufactured life which was perceived to be parasitically infecting that of the artist. For Kristine Stiles, Roberta Breitmore was 'a metaphor for traumatic multiplicity,' substantiating what she calls 'an extended reality that is an intermediary between past and future memory' (Stiles, 2001: 13). Stiles, who was the first Roberta Multiple and also present at Roberta's exorcism at Lucrezia Borgia's crypt in Italy, has written that: once Hershman projected Roberta's character onto me, she released authority over her artwork and simultaneously reestablished it. Thus began the immediate process of multiplying "Roberta Breitmores" into multiple multiples, mapping her double onto any number of willing female subjects, a multiplication that became potentially endless - and tedious to Hershman. (Stiles, 2001)

By exorcising her dark, shadowy 'flipped effigy,' Hershman hoped at the time to encourage her ‘own individuation' (Hershman, 2005a: 33).

However, not only did this prove impossible, but the timeframe for the project has retrospectively become increasingly unstable; on her website, for instance, Hershman states that the Roberta Breitmore 'investigation', conducted through 'a simulated person who interacts with real life in real time,' lasted nine years rather than four. ${ }^{3}$ Such undecidability is altogether appropriate for a work that operates through the folding back and disruption of time and space. Even in the year of Roberta's formal demise, Hershman noted that:

Death and resurrection continue through all phases of the work. Perhaps this is an attempt to reiterate the primordial chaos into immortality; perhaps it is a restatement of the cyclic nature of all being, perhaps an unconscious wish. (qtd in Schwartz, 1978: 11-12)

Hershman claims that no more than five other people knew about her project until it was 'history' (Hershman Leeson, 2010), although this seems unlikely. 
Roberta Breitmore as an artwork therefore primarily exists via archival documentation, or what Derrida might call the 'traits', of Roberta's 'life': an ad for a roommate in the San Francisco Progress, her temporary drivers license, a cassette recording of Roberta on a date at an all night sculpture show, letters she received, an acrylic ash blonde frosted wig, her dental X-ray, samples of her handwriting, excerpts from her psychiatrist's notes. The work also includes documentary surveillance photographs and portraits that have often been heavily manipulated, annotated and over-written with paint and cosmetics by Hershman, usually to emphasise processes of gender construction and/or decay. According to Robin Held, who has curated Hershman's body of work, she destabilizes understandings of time in performance 'by inextricably entwining the body-inperformance Roberta and performance-as-documentation Roberta' (2005: xii). Hershman's traces of Roberta exemplify Derrida's construction of the trait as always already doubled; it is a mark that simultaneously 'brings together and separates' the performances of veiling and unveiling, withdrawal and return. Derrida writes that ' $[T]$ he trait is itself remarked while withdrawing, it succeeds in effacing itself in an other, in re-inscribing itself there, in a parallel way, hence heterologically, and allegorically' (1998: 126; emphasis in original).

Occasionally, Hershman has made work that more figuratively represents Roberta's ephemerality and potential for transformation. One of the first images in her Water Women series, for example, entitled Roberta's Essence in Water Drops: Water, Air, Fire, was made in 1975. This is a luminous photograph of a forward-facing silhouette of a woman's body composed entirely of water droplets, her palms held invitingly open to the viewer. According to Hershman, the Water Women series, which investigates 'bodies of water' that 'reflect invisibility, evaporation, and survival,' began as a metaphor for Roberta Breitmore as well as with the 'conceptual premise of evaporation through time' (2005a: 59). She has noted that, ironically, this series about invisibility has sustained one of her 'most enduring images': 'The women are often inverted and multiplied with shifting environments' (Hershman, 2005a: 59). 
Between 1995 and 1998, Hershman created two humanoid telerobotic dolls, one of which, CybeRoberta, was a visual replica of Roberta Breitmore in miniature. She wore the same dishevelled wig, big wire-framed aviator glasses and rusty red-coloured polyester dress with white piping and polka-dotted skirt as the body-in-performance Roberta. (Interestingly, Roberta's Essence in Water Drops, which symbolises Roberta Breitmore rather than - like CybeRoberta operating as an extension or cyborgian multiple of her, employs none of these usual visual signifiers). According to Hershman, CybeRoberta, like Roberta Breitmore, 'depends on networks for access, communication, and interaction' (Hershman, 2005a: 87). I would perhaps go further and suggest that Roberta Breitmore is primarily a performative network, what Bruno Latour terms a 'well-formed assemblage' (Latour, 2005: 8). In his introduction to Actor Network Theory, Latour explains that such an assemblage, which is usually recognized as an individual body, is always semi-permanent and subject to modification and change. Although it is only possible to hint at its application here, this is one model through which we may productively connect the two phases of Hershman's art-making that have been identified by the artist and her curators: BC (Before Computers) and AD (After Digital).

Starting in 2006, Hershman also began to restage and remediate Roberta Breitmore work in the online virtual community of Second Life. ${ }^{4}$ Here, wearing the same dress and looking rather more glamorous, she is called Roberta Ware. She acts primarily as a guide to the online reconstruction of Dante's Hotel, a site-specific installation that Hershman made in 1973 just prior to creating Roberta Breitmore. In 2007, a Roberta Breitmore gallery was created in Second Life in which visitors can view images of Roberta Breitmore and the 'ephemeral' documentation of her life, in addition to framed images of her avatar, Roberta Ware, who is sometimes also present in the gallery (Figure 1). Occasionally the virtual gallery is made accessible in physical gallery spaces which are also reconstructed in Second Life (so that a visitor and her avatar can be simultaneously present in a 
gallery and its virtual reconstruction), thereby creating virtual and material archives within archives. ${ }^{5}$ As Derrida has observed,

the technical structure of the archiving archive also determines the structure of the archivable content even in its very coming into existence and in its relationship to the future. The archivization produces as much as it records the event. (1995: 17)

This resonates closely with Hershman's intentions: 'By putting the archive of my work in Second Life, I was able to transcend the original essence of the piece into a new, hybrid interactive and participatory structure' (Hershman qtd. in Linden, 2009). The use of the word 'original' in describing a project that destabilizes the concept of originality through an 'essence' that can only be recognised as and when dispersed, is a typically mischievous suggestion.

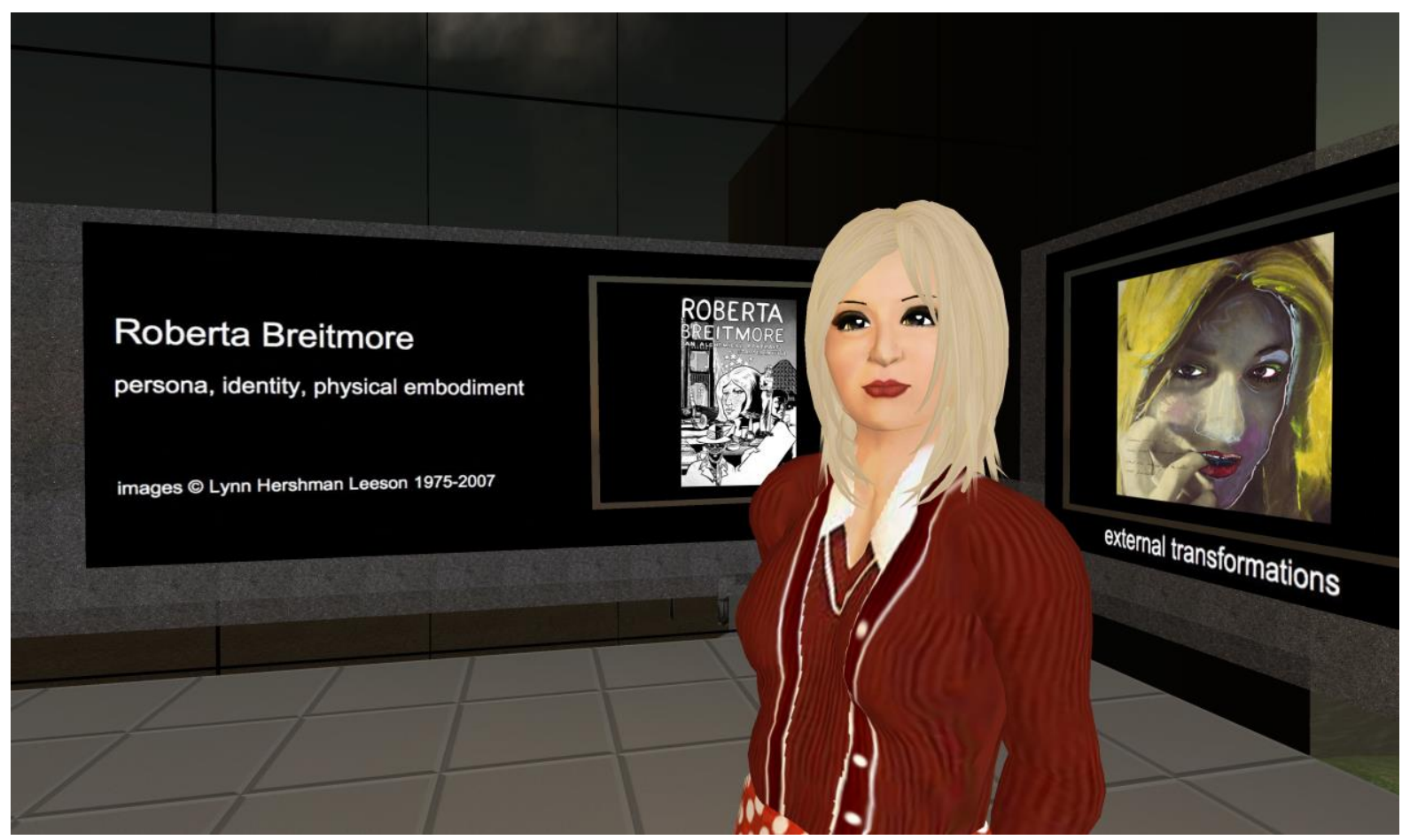

Figure 1: Roberta Ware in the Roberta Breitmore Gallery, Second Life. Image by Jeff Aldrich.

One would be hard pressed to identify an originary moment in the Roberta Breitmore project even in the lo-tech material world BC. The handful of people who encountered Hershman as Roberta Breitmore knew her only as their date or patient. Was this the original experience? Was it any more 
or less authentic than being at an art gallery event in the presence of two or three body-inperformance Roberta Multiples and surrounded by manipulated images of a different performancein-documentation Roberta on the walls (Figure 2)? I encountered photographs of Roberta artefacts on Hershman's website and in books prior to seeing the actual items in a gallery setting. The photograph of Roberta's dress(es), for instance, didn't feel any more or less 'authentic' than the material dress itself. Derrida helps to explain this phenomenon by describing the supposedly secondary trait we experience as a cut which marks divergence and 'irreducible difference' through processes of unravelling:

Now, insofar as it frays a differential splitting, a trait is neither fully originary and autonomous, nor, as fraying, purely derivative. And to the extent that such a trait frays the possibility of naming in language (written or spoken, in the accepted meaning of these words), it is not itself nameable as separation, neither literally, properly, nor metaphorically. (Derrida, 1998: 123)

The avatar Roberta Ware is and is not as authentic, originary and/nor autonomous as her namesake, the always already simulated Roberta Breitmore. They operate (and thereby signify), however, in different and more or less affective ways. Moreover, the individual viewers, audiences and participants who encounter them and their archived traces are likewise constructed and observable as complexly layered and multiple. 


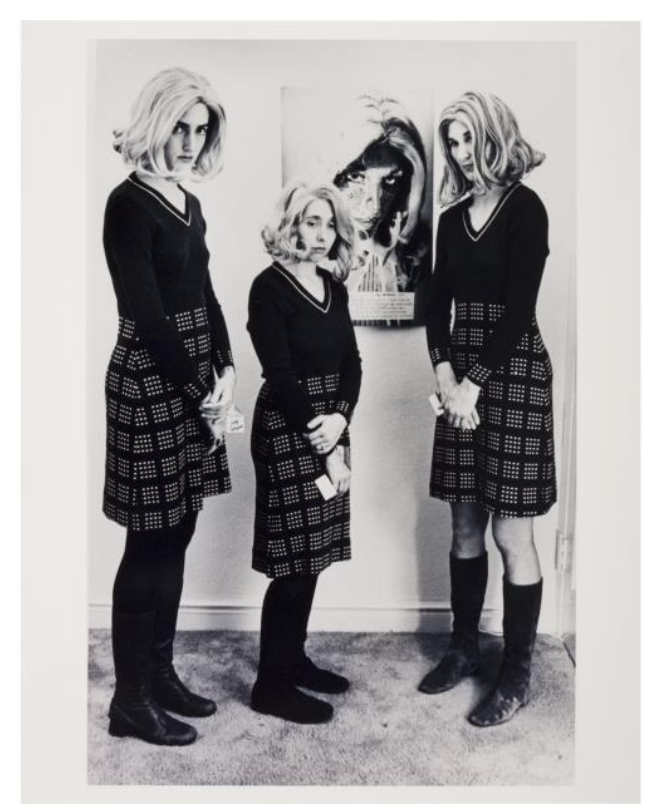

Figure 2: Roberta Multiples, 1977. Courtesy of the Whitworth Art Gallery, The University of Manchester.

\section{Roberta-Roberta}

I'm going to share some gossip.

Way back in the 1970s, the writer Joyce Carol Oates worked in the English department at the University of Windsor in Canada. She wrote many short stories, some of which were published in high profile and risqué publications like Playgirl. Oates was undeniably more visible, prolific - and successful - as a writer than most of her male colleagues. But she seemed to cause a lot of trouble. Her stories, apparently, were thinly disguised versions of real life - or to be more specific, the real lives of her colleagues, for whom Oates provided new names but very little else by which to conceal their private parts. Occasionally all hell broke loose as husbands and wives discovered their partners' infidelities through short fictions in national magazines. I could name names but I won't. The point is that this is gossip about formalized gossip that provoked a network of extended gossiping across time and space. 
Irit Rogoff has written that gossip is a form of testimony that is 'invariably located in the present.' It externalizes and makes 'overt its relations to subjectivity, voyeuristic pleasure and the communicative circularity of story-telling' (Rogoff, 2003: 268). One of many ways of understanding Lynn Hershman's Roberta Breitmore project might be to consider it structurally as gossip that acts as performative testimony to a life less lived. Drawing on the work of Patricia Spacks, Rogoff notes that gossip 'is not fictional, but both as oral and written form, it embodies the fictional [and] impels plot' (274). Gossip, she says, bears 'a multiple burden.' Because it is 'unauthored, untraceable and unfixed in historical time' (269), it can be read as a phantasmic projection of various desires by its audiences onto cultural narratives which it thus shapes (272). It is perhaps for this reason that the glamour of tawdry illicit sex involving people I had met (even if this sex happened long before I met them), as well as the existence of an internationally respected woman artist who once lived in Windsor, Ontario - my own, seemingly unremarkable, provincial hometown - captured my teenage imagination with such fervour.

In 1985, a few years after Joyce Carol Oates left Windsor, I was a columnist for the University's student newspaper. I mainly wrote about myself. I remember a particular piece in which I reflected upon being named Roberta and listed most of the Robertas I had encountered so far. One of them was the transsexual ex-football player, Roberta Muldoon, in John Irving's novel, The World According to Garp (1978). Those who study things Roberta repeatedly come across this gender excess as transformative trope. Lynn Hershman, for instance, describes Roberta Breitmore as 'an androgynous construction of doubles, from her name, which is an adaptation of a masculine Robert, to her image, to her sexual relationship with her brother at 13' (qtd. in Schwarz, 1978: 10). Robertas tend to be suspiciously masculine, or try too hard at being feminine. Their sexualities are often selfdestructive. In the process of proliferating gender, the means of its recognition often seems to be explosively evacuated from Roberta bodies. 
Had I been paying just a bit more attention, I might have mentioned another Roberta a little closer to home. In 1973, Joyce Carol Oates published a short story entitled 'Passions and Meditations' in The Partisan Review about a character called Roberta Bright who stalks a composer with increasing ferocity over the period of six weeks. The narrative is revealed only through Roberta's letters, one of which includes an ignored classified ad that Roberta placed in the Village Voice, requesting a meeting with her object of desire. It is at about this point that Roberta, who introduces herself originally as a 26 year old woman, starts to sign herself simply as R. Bright and admits that she's 'Not a young woman, no. Not young. Not a woman.' She tells the composer that he has 'looked right at her' and suggests that she might have been the beggar he passed in the street, or 'the man in the blue suit who stepped aside' so he could go into a restaurant, or the boy dressed in black who followed him 'into that drug store on $59^{\text {th }}$ Street' (Oates, 1980: 163).

Lynn Hershman has said that Roberta Breitmore's name derives from this story, and it is easy to discern some of the formal elements her work shares with Oates': the construction of narrative through gossip and ephemeral documents, the centrality of voyeurism and surveillance to these narratives, the onesidedness of the documentation, the slippery ambiguity of an identity that blurs fact and fiction, a person who blinks in and out of sight. But Roberta Breitmore is no translation or theatrical adaptation of Roberta Bright; indeed, there's every reason to believe that Hershman's Roberta existed before she was named, before Hershman read Oates' story. It is instead more productive to think of each in terms of place - and, in particular, the processual qualities of dis- and re-placement in space and time. As Derrida reminds us in 'The Time before First,' beginnings are really reiterative retrospective articulations: 'All opposition based on the distinction between the original and the derived, the simple and the repeated, the first and the second, etc., lose their pertinence from the moment everything "begins" by following a vestige. i.e. a certain repetition or text' (Derrida, 1998: 130). 
While Hershman's very brief plot description of 'Passions and Meditations' is otherwise fairly inaccurate, she does draw our attention to one of Oates' central motifs thereby indicating its significance to her: that is, the black hole (Hershman, 2005a: 33). Roberta Bright repeatedly identifies herself as a burned-out star. She writes that 'no light can come out of them: the light is dragged back into them by their powerful gravity.... they are dead, more than dead.... I am one of those black holes. A point of consciousness condensed in upon itself' (Oates, 1980: 159). In her next letter to the composer, she notes that as a black hole, she is 'invisible' and able to 'enter the back doors of lives' (160). Roberta's final letter is the most chilling, clearly indicating that her name is meant to be ironic, that she symbiotically feeds off light and is co-constituted by the brightness of others: 'We are united. A point of flaming rushing light, a "star"... and his mate, a black hole...a speaking breathing chewing worshipping hole ...a fan. Your death won't delight you, but it will delight me... Other people will forget you...I will remember... forever and ever. I will cherish every morsel of news, every scrap of gossip' (164-165).

In 2008, the Whitworth Gallery in Manchester acquired a 'complete' Roberta Breitmore collection. One of its nearly 200 pieces is a print of what looks like a page from a science textbook entitled 'Black Holes, Space, Time and Roberta.' It seems to have been made in $1978,{ }^{6}$ for the catalogue of a solo exhibition entitled Lynn Hershman is not Roberta Breitmore/Roberta Breitmore is not Lynn Hershman at the M. H. de Young Memorial Museum in San Francisco. Like Roberta Bright's relationship with black holes, Roberta Breitmore's is metonymical. We read that 'Roberta's personality reveals the microcosmic individual world through which a macrocosmic view of the universe surfaces.' After a paragraph explaining black holes and their causes (at least as they were understood in the late 1970s), we are told rather laconically that 'Approaching a black hole is not pleasant. Fragmentation occurs.' The text then juxtaposes two mathematical equations, each of which includes the variable ' $\mathrm{R}$ '. The first is borrowed from William J. Kaufmann's The Cosmic 
Frontiers of General Relativity in which R, the radius of a black hole, is presented as gravity mass divided by the speed of light. This is followed by an equation for Roberta:

R equals Roberta equals Experience divided by Speed of Life equals Change over Time.

As this equation suggests, to embrace the name Roberta, especially in the course of art-making, is to consciously engage in a specific type of performative spatio-temporal process. I realize this may seem slightly ludicrous so here's another example: the British artist, Bob and Roberta Smith, whose 'real' name is neither Bob nor Roberta (although apparently his sister's is). According to Bob and Roberta, 'artworks are networks' and, like Lynn Hershman's, his work can be understood in terms of what Nicholas Bourriaud has called 'relational aesthetics.' Bob and Roberta is interested in 'putting an activity in a space rather than an artwork, [and] using the real talents of people' (qtd. in Miller, 2006).

I suspect that you are somewhat relieved. I suspect you were becoming rather concerned that I was getting dangerously close to proposing some kind of essential Robertaness. Of course not. This is all about becoming, not being.

The processes of becoming 'and Roberta' mimic the unstable operation of naming itself as described by Derrida. For Derrida the 'so-called proper name'

is always caught in a chain or a system of differences. It becomes an appellation only to the extent that it may inscribe itself within a figuration.... A signifier is from the very beginning the possibility of its own repetition, of its own image or semblance. From the moment that the sign appears, that is to say, from its very beginning, there is no chance of 
encountering anywhere the purity of 'reality', 'unicity', 'singularity'. (Derrida, 1976: 8991)

Amelia Jones has noted that Lynn Hershman's use of naming to perform herself as both artist and subject unhinges our tendency to believe we 'know' who somebody is through the 'shorthand' of her name. 'Enacting a perpetual process of virtual becoming,' she writes, 'Hershman stages the self as both simulacral and embodied. $\mathrm{LH} \longleftrightarrow \longrightarrow \mathrm{RB}$ : they exist as the interrelated sides of one Möbius strip of selfhood' (Jones, 2008). In Jones's formulation, the artwork is 'the LH $\rightarrow \mathrm{RB}$ matrix' and, it seems, our response to - and incorporation in - it, relies upon what Derrida would call its inherent 'spacing.' According to Jones, we think Roberta Breitmore 'through our bodies (perhaps we are the arrows in the liminal gap between the LH and the RB).' Multiplicity breeds the space in which to multiply. We create and are potentially created by the complex relationship between Hershman and Roberta.

Roberta Breitmore overtly plays out the implications of signification caught in a chain of differences. Roberta is the clumsy feminization of Robert, an ancient German name, meaning 'bright fame.' She is doubled ironically to become Roberta Bright who then becomes R. Bright. We 'are bright': plural. Lynn Hershman's Roberta, absorbing ever more bodies and their experiences, is even more bright (or else, like a black hole, absorbs even more light to constitute herself).

Hershman has described Roberta as 'a portrait. She is at once an invisible human double as well as a mirror magnet' (qtd. in Schwartz, 1978: 10).

I return here to my solipsistic student writing in 1985 and the most then-recent, and perhaps embarrassingly influential, Roberta in whose performance I imagined myself. That was the year Susan Seidelman's Desperately Seeking Susan was released - a movie occasionally and variously described as being based on either Oates' short story or Hershman's long term performance project. In it, Rosanna Arquette plays Roberta Glass, a bored New Jersey housewife who vicariously 
follows the adventures of the flamboyant Susan, played by Madonna, through Village Voice personal ads, before wackily getting caught up in the action and becoming Susan through mistaken identity and amnesia. Roberta not only joins Susan through the looking glass but mirrors her brightness and fame. I completely understand why I was so attracted to Roberta Glass - in her, I saw my suburban future and paradoxical invisibility. I too wanted to be Madonna/Susan; or rather, I wanted to be Roberta as Madonna/Susan. In Roberta Glass - like in Roberta Breitmore (- and also as I often do, although quite differently, in Jacques Derrida) - I saw my Jewishness performed, multiplied and transformed.

My attraction to Roberta-Susan was based on her excessive extra-ordinariness; she was neither, and more than the sum, of her parts. She lived the world through a single body but saw it through two different sets of eyes. In this, she most resembles Lynn Hershman's CybeRoberta made a decade later (Figure 3), and known collectively with her sister, Tillie the Telerobotic Doll, as The Dollie Clones. Each had a video camera in one eye and a web cam in the other. Internet users could manipulate their heads in order to see the gallery in which the dolls were physically located, and visitors in the gallery space could see the image of themselves that would be sent back to the webpage on a small monitor. Those who engaged with this piece became voyeurs through the mask of the dolls who, when exhibited together, were able to pirate each other's information. According to Hershman, Tillie and CybeRoberta expanded 'the possibilities of singular identity into a networked trajectory composed of flowing data that eats itself, cannibalizing in the process information that mutates and is re-expressed in unpredictable ways. Individual interaction results in both immediate response as well as in re-patterned cultural demographics that reveal cultural patterns' (Hershman, 2005b: 209). 


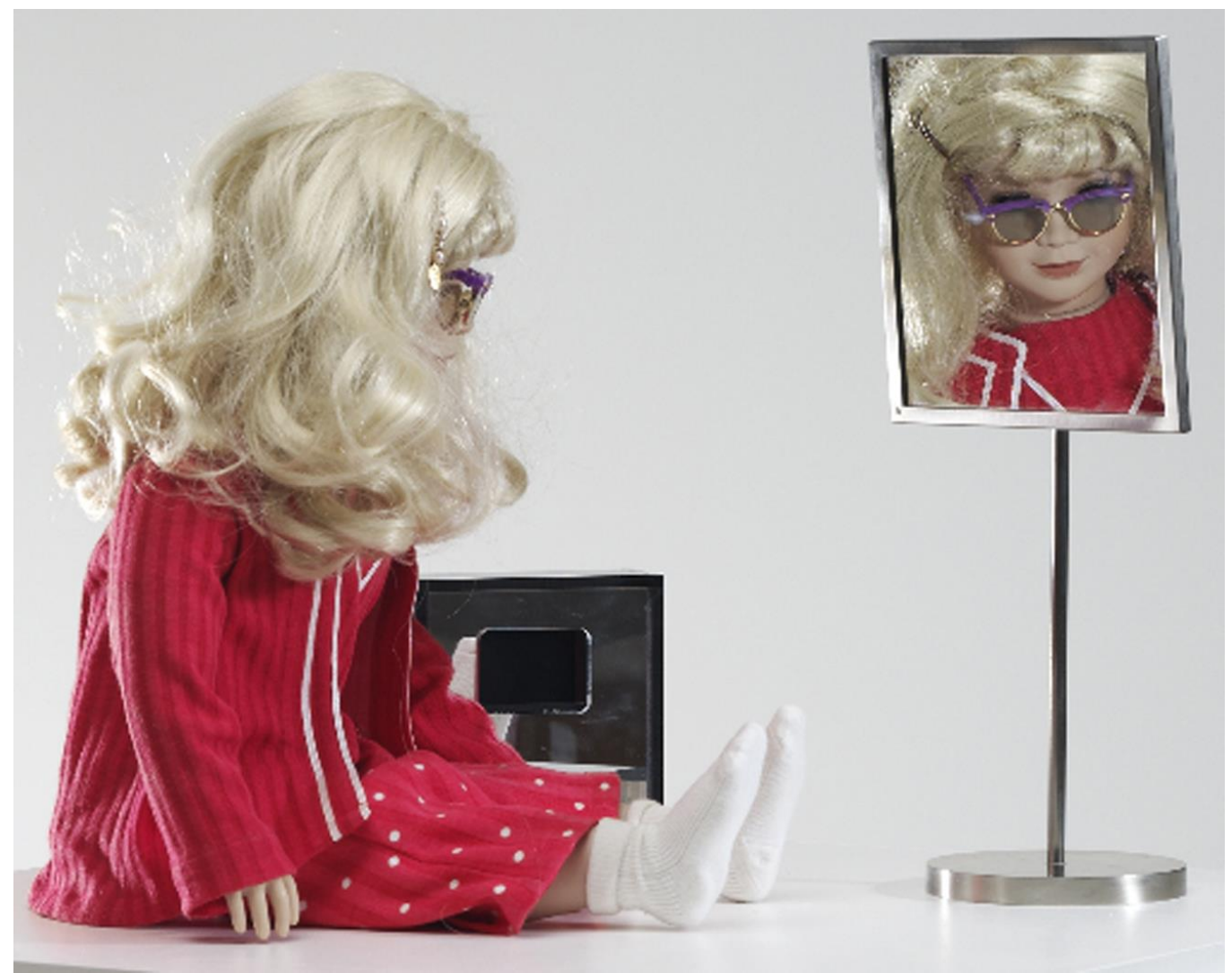

Figure 3: CybeRoberta. Photo courtesy of Lynn Hershman Leeson.

\section{Roberta of the Living-Dead}

There is a manually typed, undated document entitled 'Retrospective Notes' in the Whitworth Roberta Breitmore archive which, when I encountered it, had not yet been catalogued by the gallery. It seems to be the basis from which most of Hershman's 'official' writing on Roberta derives, as if she were testing out the ideas for the first time. Even in her conceptual articulation, Roberta Breitmore is continuously revised and annotated. Some of the material in these notes feels uncomfortably intimate and indeed, does not appear elsewhere. The following passage, however, does, in a variety of ways:

Roberta operates like a sociologist. Interviewing people and noteing [sic] their reactions. As Roberta becomes more real the people she meets become fictionalized participants in her adventures.... She is the mythical invisible death image, personified. 
Hershman's terminology - and indeed her practice, moving from social encounter to archival documentation - reminds me of Roland Barthes' in Camera Lucida in which he connects theatre and photography through an invocation of absence and death. It is no coincidence that, as Glenn Kurtz has noted, Hershman 'has pursued a sophisticated visual aesthetic at the confluence of photography, theater, painting, and collage' (Kurtz, 2005: 114). For Barthes, photography is 'a kind of Tableau Vivant, a figuration of the motionless and made-up face beneath which we see the dead' (Barthes, 1993: 32).

It is this understanding of death - 'this will be and this has been' (Barthes, 1993: 96; emphasis in original) - that enables the operation of the punctum, which is perhaps best understood as a spectator's individual affective response to a detail in a photographic image. According to Barthes, the punctum is a 'blind field' that 'constantly doubles our partial vision' (57). It is 'what I add to the photograph and what is nonetheless already there' (55). It is a wound, 'an accident which pricks' and 'bruises me' and, significantly, a 'little hole' (27). The punctum I experience in the visual manifestations of Roberta Breitmore's absence reinforces my own body's presence and places it in a continuum of experience and signification. $\mathrm{R}=$ Change over Time.

According to Derrida, le mal d'archive or 'archive fever' derives from the coexistence of 'archival desire' and the 'death drive' (1995: 14) and, certainly for me, there are times when Roberta Breitmore's multiples and archival traces signal closer to absence than presence. Roberta Ware may be inherently augmented but I find her glossy surface difficult to rend apart; her blonde hair is no longer a wig liable to slippage; her body is never at risk amongst similarly simulated bodies. Trapped in her own virtual archival gallery, surrounded by images of her past lives, this Roberta seems dangerously close to becoming frozen in what Derrida calls the 'in-finite movement of radical destruction' (1995: 59), even as she is being ‘driven' by percipients during a gallery-based '24 Hour Roberta' event. ${ }^{7}$ Indeed, in 2006 Hershman made an edition of eight miniature resin 
statues of Roberta Ware modelled on the Second Life avatar, each presented in what reminds me of a mirrored plexiglass coffin. Hershman exhibited one in her solo show at bitforms gallery in New York entitled Found Objects, alongside a lifesize 'sex doll' of Manet's Olympia. Discussing these 'fantasy dolls' Hershman said that, 'The Olympia doll is very similar to Roberta and the media's projections of women in the 1970s. It is the study of something that never existed. It exists only by what you presume' (qtd. in Buhmann, 2008).

While developing the ideas in this chapter, I had a conversation with a friend who was corresponding with Joyce Carol Oates. I told him that I couldn't help wondering whether Roberta Bright was based on a real person and, if so, whether she (or he) was either Jewish or named Roberta. A few weeks later, I received this in an email from him: 'I asked JCO about the woman you're interested in. She said that she could not comment.' My friend didn't know whether this meant she wouldn't or that she couldn't remember the source, but he believed that I was almost certainly correct in believing that there had been a 'real-life model.' We had a good gossip about it and I am now more content in my not knowing. What excites me are the lived experiences that connect me to somebody who probably existed, the networked bodies that I am archiving here through and in the process of writing.

In the Whitworth's collection there is a little metal badge from 1978 which reads 'Roberta Lives inside me' over the graphic of a red star. ${ }^{8}$ I wish I had one. I believe that the badge was made for a Roberta look-a-like contest that attracted, among others, transvestites, young girls and a set of elderly female twins. Robin Held has written that as 'the contestants vied to win, Roberta was fractured and dispersed across their bodies' (Held, 2005: xiii). Photographs of these bodies were then reprocessed through paint, collage and annotation like the other photographs featuring Roberta-Lynn and the three 'original' Roberta Multiples before entering into the circulation of the Roberta ecology. In May 2010 at the Whitworth, Hershman commented on the absurdity of a 
collection called 'The Complete Roberta Breitmore': 'Roberta isn't complete,' she said. 'She transforms and mutates' through processes of improvisation and documentation. 'All of the people who engage with Roberta continue to embody her' (Hershman Leeson, 2010).

\section{Notes}

${ }^{1}$ Since the late 1990 s, and especially as she moved into feature film making, the artist has predominantly used her married name, 'Lynn Hershman Leeson'. I have chosen to use 'Lynn Hershman' as this was her name when creating the first iteration of Roberta Breitmore and under which she most often exhibited until quite recently. Given my focus here on multiplicity, naming and the recognition of relational networks, this was not a decision taken lightly. Tromble (2005b) referred to 'Hershman' in the critical essays but used the more inclusive name 'Hershman Leeson' for the title of her edited book.

${ }^{2}$ I am borrowing the term percipient from Misha Meyers who uses it to describe a 'particular kind of participant whose active, embodied and sensorial engagement alters and determines a process and its outcomes' (2008: 173).

${ }^{3}$ The quotation is from the Roberta Breitmore documentation pages on <www.lynnshershman.com $>$ where the duration of the work is specified at four years. On <http://www.lynnhershman.com/investigations/privatei/roberta_breitmore/roberta_breitmore2.html $>$, however, the duration is nine years and, elsewhere, it is described as either three or five. Both webpages accessed 1 March 2011. 
${ }^{4}$ Hershman worked with Stanford Humanities Lab on this project, entitled 'Life Squared', which explored ways of re-animating the existing archive of her work to engage new audiences. See <http://www.stanford.edu/group/shl/cgi-bin/drupal/?q=node/31 > accessed 1 September 2010.

${ }^{5}$ See, for instance, the documentation of Life Squared as part of the exhibition 'e-art: New Technologies and Contemporary Art: Ten years of accomplishments by the Daniel Langlois Foundation' (Montreal Museum of Fine Arts, 2007) at <http://spa.exeter.ac.uk/drama/presence/presence.stanford.edu_3455/Collaboratory/1190.html> accessed 1 March 2011.

${ }^{6}$ Whitworth acquisition lists it as 1977 and the title as 'Black Holes in Space time and Roberta' which is at odds with the documentation on the DVD that accompanies The Art and Films of Lynn Hershman Leeson (Tromble, 2005b). The DVD also identifies the 'author' of the equation as Robert Harris.

${ }^{7}$ 24-Hour Roberta was part of the exhibition The Future Lasts Forever at SF Camerawork, 27 March 2010. See <http://www.sfcamerawork.org/events/index.php?id=68\&month=03\&year=2010> accessed 15 March 2011.

8 'Roberta Lives [inside me]' (P.2008.22.141), Whitworth Art Gallery, Manchester.

\section{References}

Barthes, Roland (1993) Camera Lucida: Reflections on photography. Trans. Richard Howard. London: Vintage. 
Buhmann, Stephanie (2008) 'Art of the artificial: Lynn Hershman Leeson explores media, fantasy and Manet', The Villager, 77: 51, 21-27 May http://www.thevillager.com/villager_264/artoftheartificial.html> accessed 1 March 2011. claire_w (2009) 'Interview: Lynn Hershman Leeson in conversation with claire_w', Interventtech < http://interventtech.net/2009/02/28/interview-lynn-hershman-leeson-in-conversation-withclaire_w/> accessed 1 December 2010.

Derrida, Jacques (1976) Of Grammatology. Trans. G.C. Spivak. Baltimore: Johns Hopkins University Press.

Derrida, Jacques (1995) ‘Archive Fever: A Freudian Impression’, Trans. Eric Prenowitz. Diacritics, 25: 2 (Summer), pp. 9-63.

Derrida, Jacques (1998) The Derrida Reader: Writing Performances, Ed. Julian Wolfreys. Edinburgh: Edinburgh University Press.

Held, Robin (2005) 'Forward: Hershmanlandia', in The Art and Films of Lynn Hershman Leeson, Ed. M. Tromble, pp. xi-xix.

Hershman, Lynn (2005a) 'Private I: An Investigator's Timeline', in The Art and Films of Lynn Hershman Leeson, Ed. M. Tromble, pp. 13-103.

Hershman, Lynn (2005b) 'The Raw Data Diet, All-Consuming Bodies and the Shape of Things to Come', Leonardo, 38: 3, pp. 208-212. 
Hershman Leeson, Lynn (2010) Speaking at The Complete Roberta Breitmore Symposium, Whitworth Art Gallery, Manchester, 15 May.

Jones, Amelia (2008) 'This Life' in Frieze, Issue 117, September

<http://www.frieze.com/issue/article/this_life/> accessed 24 August 2010.

Kurtz, Glenn (2005) ‘Composing with Images: Lynn Hershman’s Photography’, in The Art and Films of Lynn Hershman Leeson, Ed. M. Tromble, pp. 113-125.

Latour, Bruno (2005) Resembling the Social: An Introduction to Actor Network Theory. Oxford \& New York: Oxford University Press.

Linden, Robin (2009) 'Stories From Second Life: Hotwire Island and Lynn Hershman Leeson’, Official Second Life Blog, 5 January http://lindenlab.wordpress.com/2009/01/05/stories-fromsecond-life-hotwire-island-and-lynn-hershman-leeson/ > accessed 15 March 2011.

Myers, Misha (2008) 'Situations for living: performing emplacement', Research in Drama Education: The Journal of Applied Theatre and Performance, 13: 2, pp. 171-180.

Miller, Mitchell (2006) 'Upside Down is the New Rightside Up: Bob and Roberta Smith'< http://www.saatchi-gallery.co.uk/blogon/2006/09/bob_and_roberta_smith_intervie_1.php > accessed 7 September 2010.

Oates, Joyce Carol (1980) The Seduction and Other Stories, New York: Fawcett Crest Books. 
Rogoff, Irit (2003) 'Gossip as Testimony: A Postmodern Signature', in The Feminism and Visual Culture Reader. Ed. Amelia Jones. London and New York: Routledge, pp. 268-276.

Schwarz, Arturo (1978) 'Who is Roberta Breitmore? (Some Preliminary Remarks on the Origin and Development of an Alchemical Opus)'. Essay included on the DVD accompanying The Art and Films of Lynn Hershman Leeson (Tromble, 2005b). Also available <http://lynnhershman.com/lfiles/Schwarz.pdf> accessed 1 April 2011.

Stiles, Kristine (2001) Return to Double: Revisiting Roberta Breitmore [cached by Google] <http://www.trauma-interrupted.org/stiles/Writing3.pdf $>$ accessed 2 August 2010.

Tromble, Meredith (2005a) 'Double Talk: The Counterstory of Lynn Hershman', in The Art and Films of Lynn Hershman Leeson, Ed. M. Tromble (2005b), pp. 200-207.

Tromble, Meredith, ed. (2005b) The Art and Films of Lynn Hershman Leeson: Secret Agents, Private I. Berkeley and Seattle: University of California Press and Henry Art Gallery, University of Washington. 